Check for updates

Cite this: RSC Adv., 2019, 9, 32081

Received 6th August 2019

Accepted 18th September 2019

DOI: $10.1039 / \mathrm{c} 9 \mathrm{ra0} 6108 \mathrm{~h}$

rsc.li/rsc-advances

\section{Palladium-catalyzed oxidative cross-coupling for the synthesis of $\alpha$-amino ketones $\uparrow$}

\author{
Xiao-Hong Wei, (D) * Zhen-Hua Li, (D) * Lian-Biao Zhao, Ping Zhang, \\ Han-Cheng Zhou (D) and Yan-Bin Wang
}

A novel oxidative cross-coupling reaction for the synthesis of $\alpha$-aryl $\alpha$-amino ketones in the presence of palladium catalysts using $\mathrm{T}^{+} \mathrm{BF}_{4}{ }^{-}$as an oxidant has been developed. This transformation was achieved by direct $\mathrm{C}-\mathrm{H}$ oxidation of $\alpha$-aminocarbonyl compounds and arylation. The mild reaction has a broad reaction scope and gives desired $\alpha$-aryl $\alpha$-amino ketones in moderate to excellent yields.
Transition metal-catalyzed oxidative coupling reactions involving the formation of $\mathrm{C}-\mathrm{C}$ bonds from $\mathrm{C}-\mathrm{H}$ bonds have attracted considerable attention, indicating excellent atom economy and environmental friendliness. ${ }^{1} \alpha$-Amino carbonyl compounds have important roles in natural products and are the key structural units of natural products. ${ }^{2}$ These compounds have also been used in organic chemistry to synthesize biological activites, therapeutic agents, quinazolines, imidazoles, pyrazines, indoles, and pyrroles. ${ }^{3}$ Therefore, the direct oxidative $\mathrm{C}-\mathrm{H}$ functionalization has gained significant attention for the synthesis of a series of $\alpha$-amino carbonyl compounds..$^{2 i, 2 j, 4}$ For example, Li's group employed an oxidative coupling reaction to synthesize $\alpha$-amino carbonyl compounds from $N$-glycine derivatives by direct $\mathrm{C}-\mathrm{C}$ bond formation under the catalysis of copper salts. ${ }^{5}$ Subsequently, stoichiometric amounts of chemical oxidants, such as DTBP, DDQ, TBHP, and 2,2,6,6tetramethylpiperidine-1-oxoammonium tetra-fluoroborate $\left(\mathrm{T}^{+} \mathrm{BF}_{4}{ }^{-}\right)$, have been applied to these reactions. ${ }^{4 a, 4 d, 4 p, 4 t, 6}$ In 2013, Yang's group described a novel protocol for a coppercatalyzed oxidative phosphonation reaction by using $\alpha$-aminocarbonyls and diphenylphosphine ((1), Scheme 1). ${ }^{7}$ Huang's group disclosed a general and efficient method for $\mathrm{C}-\mathrm{N}$ oxida-

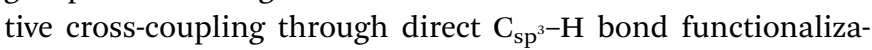
tion of $\alpha$-aminocarbonyl compounds with amines under the catalysis of copper salts ((2), Scheme 1).$^{\text {hh }}$ In 2015, Yang's group developed a highly efficient route to synthetize chiral arylglycine derivatives via a palladium-catalyzed enantioselective direct C-H oxidation arylation reaction ((3), Scheme 1). ${ }^{4 p}$ Furthermore, transition metal-catalyzed direct $\mathrm{C}-\mathrm{H}$ functionalization by an oxidative cross-coupling reaction has been reported in the past few years. ${ }^{8}$ Although significant advances have been made along

Key Laboratory for Utility of Environment-Friendly Composite Materials and Biomass in University of Gansu Province, College of Chemical Engineering, Northwest Minzu University, Lanzhou 730030, P. R. China. E-mail: weixh12@lzu.edu.cn; lizhh02006@163.com

$\dagger$ Electronic supplementary information (ESI) available. See DOI: $10.1039 / \mathrm{c} 9 \mathrm{ra} 06108 \mathrm{~h}$ these lines, the development of efficient synthetic methodologies for the synthesis of $\alpha$-aminocarbonyl compounds via palladium-catalyzed oxidative cross-coupling still remains a challenging topic. Based on these considerable progresses, in this paper, we describe a highly efficient $\mathrm{C}-\mathrm{H}$ oxidative crosscoupling reaction strategy for the synthesis of $\alpha$-amino ketone compounds by palladium-catalyzed direct $\mathrm{C}-\mathrm{H}$ oxidation and arylation reactions ((4), Scheme 1$)$.

In an initial study, we chose 2-((4-chlorophenyl)amino)-1phenylethanone 1a and para-methylphenyl boric acid as the model substrate to evaluate different oxidants in the presence of $10 \mathrm{~mol} \% \mathrm{Pd}(\mathrm{OAc})_{2}$ with 2,2-bipyridine as a ligand in TFE at $60{ }^{\circ} \mathrm{C}$ (Table 1, entries 1-8). To our delight, the desired product 2a was obtained in $14 \%$ yield by using 2,2,6,6tetramethylpiperidine-1-oxoammonium tetra-fluoroborate $\left(\mathrm{T}^{+} \mathrm{BF}_{4}{ }^{-}\right)^{4 p}$ as an oxidant (Table 1, entry 8). Based on these results, various ligands were used to carry out the reaction in the presence of $10 \mathrm{~mol} \% \mathrm{Pd}(\mathrm{OAc})_{2}$. As expected, the best result of $29 \%$ yield was obtained by employing $\mathbf{L}_{3}$ as a ligand (Table 1 ,

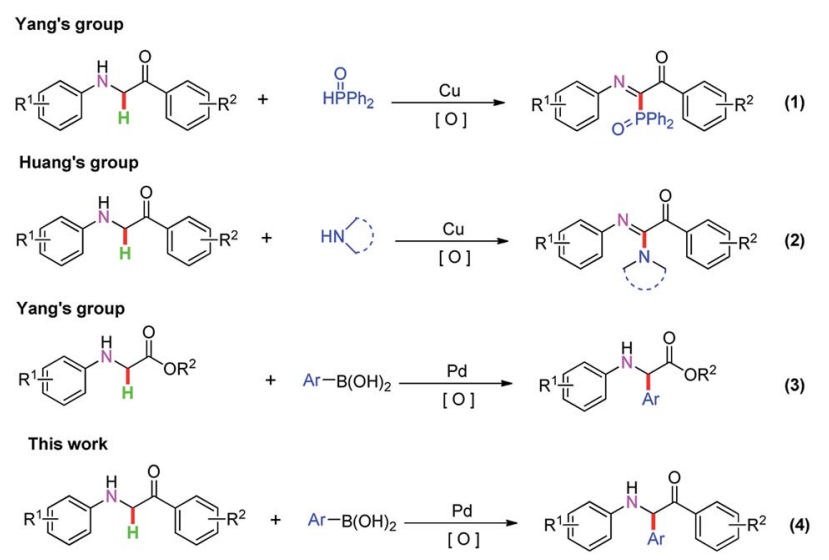

Scheme 1 Transition metal-catalyzed reaction for the synthesis of $\alpha$ aminocarbonyl compounds. 
Table 1 Optimization of the reaction conditions $s^{a, b}$

\begin{tabular}{|c|c|c|c|c|c|}
\hline Entry & Catalyst & Ligand & Oxidant & Solvent & Yield $^{b}$ \\
\hline 1 & $\mathrm{Pd}(\mathrm{OAc})_{2}$ & bpy & $\mathrm{BQ}$ & TFE & $10 \%$ \\
\hline 2 & $\mathrm{Pd}(\mathrm{OAc})_{2}$ & bpy & $\mathrm{Ag}_{2} \mathrm{CO}_{3}$ & TFE & $13 \%$ \\
\hline 3 & $\mathrm{Pd}(\mathrm{OAc})_{2}$ & bpy & $\mathrm{K}_{2} \mathrm{~S}_{2} \mathrm{O}_{8}$ & TFE & Trace \\
\hline 4 & $\mathrm{Pd}(\mathrm{OAc})_{2}$ & bpy & Air & TFE & $8 \%$ \\
\hline 5 & $\mathrm{Pd}(\mathrm{OAc})_{2}$ & bpy & $\mathrm{PhI}(\mathrm{OAc})_{2}$ & TFE & Trace \\
\hline 6 & $\mathrm{Pd}(\mathrm{OAc})_{2}$ & bpy & $\mathrm{Ph}_{3} \mathrm{CBF}_{4}$ & TFE & NR \\
\hline 7 & $\mathrm{Pd}(\mathrm{OAc})_{2}$ & bpy & $\mathrm{C}_{7} \mathrm{H}_{7} \mathrm{BF}_{4}$ & TFE & Trace \\
\hline 8 & $\mathrm{Pd}(\mathrm{OAc})_{2}$ & bpy & $\mathrm{T}^{+} \mathrm{BF}_{4}^{-}$ & TFE & $14 \%$ \\
\hline 9 & $\mathrm{Pd}(\mathrm{OAc})_{2}$ & $\mathbf{L}_{\mathbf{1}}$ & $\mathrm{T}^{+} \mathrm{BF}_{4}^{-}$ & TFE & $24 \%$ \\
\hline 10 & $\mathrm{Pd}(\mathrm{OAc})_{2}$ & $\mathbf{L}_{2}$ & $\mathrm{~T}^{+} \mathrm{BF}_{4}^{-}$ & TFE & $13 \%$ \\
\hline 11 & $\mathrm{Pd}(\mathrm{OAc})_{2}$ & $\mathbf{L}_{3}$ & $\mathrm{~T}^{+} \mathrm{BF}_{4}^{-}$ & TFE & $29 \%$ \\
\hline 12 & $\mathrm{Pd}(\mathrm{OAc})_{2}$ & $\mathbf{L}_{4}$ & $\mathrm{~T}^{+} \mathrm{BF}_{4}^{-}$ & TFE & $15 \%$ \\
\hline 13 & $\mathrm{Pd}(\mathrm{OAc})_{2}$ & $\mathbf{L}_{5}$ & $\mathrm{~T}^{+} \mathrm{BF}_{4}^{-}$ & TFE & $20 \%$ \\
\hline 14 & $\mathrm{Pd}(\mathrm{OAc})_{2}$ & $\mathbf{L}_{6}$ & $\mathrm{~T}^{+} \mathrm{BF}_{4}^{-}$ & TFE & $12 \%$ \\
\hline 15 & $\mathrm{Pd}(\mathrm{OAc})_{2}$ & $\mathrm{PPh}_{3}$ & $\mathrm{~T}^{+} \mathrm{BF}_{4}^{-}$ & TFE & $16 \%$ \\
\hline 16 & $\mathrm{Pd}(\mathrm{OAc})_{2}$ & $\mathbf{L}_{3}$ & $\mathrm{~T}^{+} \mathrm{BF}_{4}^{-}$ & DCE & $21 \%$ \\
\hline 17 & $\mathrm{Pd}(\mathrm{OAc})_{2}$ & $\mathbf{L}_{3}$ & $\mathrm{~T}^{+} \mathrm{BF}_{4}^{-}$ & THF & $31 \%$ \\
\hline 18 & $\mathrm{Pd}(\mathrm{OAc})_{2}$ & $\mathbf{L}_{3}$ & $\mathrm{~T}^{+} \mathrm{BF}_{4}^{-}$ & TOL & Trace \\
\hline 19 & $\mathrm{Pd}(\mathrm{OAc})_{2}$ & $\mathbf{L}_{3}$ & $\mathrm{~T}^{+} \mathrm{BF}_{4}^{-}$ & $\mathrm{CH}_{3} \mathrm{NO}_{2}$ & 16 \\
\hline 20 & $\mathrm{Pd}(\mathrm{OAc})_{2}$ & $\mathbf{L}_{3}$ & $\mathrm{~T}^{+} \mathrm{BF}_{4}^{-}$ & DCM & $18 \%$ \\
\hline 21 & $\mathrm{Pd}(\mathrm{OAc})_{2}$ & $\mathbf{L}_{3}$ & $\mathrm{~T}^{+} \mathrm{BF}_{4}^{-}$ & $\mathrm{C}_{2} \mathrm{H}_{5} \mathrm{OH}$ & $37 \%$ \\
\hline 22 & $\mathrm{Pd}(\mathrm{OAc})_{2}$ & $\mathbf{L}_{3}$ & $\mathrm{~T}^{+} \mathrm{BF}_{4}^{-}$ & DME & $40 \%$ \\
\hline 23 & $\mathrm{Pd}(\mathrm{OAc})_{2}$ & $\mathbf{L}_{3}$ & $\mathrm{~T}^{+} \mathrm{BF}_{4}^{-}$ & DMF & $8 \%$ \\
\hline 24 & $\mathrm{Pd}(\mathrm{OAc})_{2}$ & $\mathbf{L}_{3}$ & $\mathrm{~T}^{+} \mathrm{BF}_{4}^{-}$ & Dioxane & $32 \%$ \\
\hline 25 & $\mathrm{Pd}(\mathrm{OAc})_{2}$ & $\mathbf{L}_{3}$ & $\mathrm{~T}^{+} \mathrm{BF}_{4}^{-}$ & $\mathrm{CH}_{3} \mathrm{OH}$ & $47 \%$ \\
\hline $26^{c}$ & $\mathrm{Pd}(\mathrm{OAc})_{2}$ & $\mathbf{L}_{3}$ & $\mathrm{~T}^{+} \mathrm{BF}_{4}^{-}$ & $\mathrm{CH}_{3} \mathrm{OH}$ & $23 \%$ \\
\hline $27^{d}$ & $\mathrm{Pd}(\mathrm{OAc})_{2}$ & $\mathbf{L}_{3}$ & $\mathrm{~T}^{+} \mathrm{BF}_{4}^{-}$ & $\mathrm{CH}_{3} \mathrm{OH}$ & $71 \%$ \\
\hline $28^{d}$ & $\mathrm{Pd}\left(\mathrm{NO}_{3}\right)_{2}$ & $\mathbf{L}_{3}$ & $\mathrm{~T}^{+} \mathrm{BF}_{4}^{-}$ & $\mathrm{CH}_{3} \mathrm{OH}$ & $56 \%$ \\
\hline $29^{d}$ & $\operatorname{Pd}(\mathrm{TFA})_{2}$ & $\mathbf{L}_{3}$ & $\mathrm{~T}^{+} \mathrm{BF}_{4}^{-}$ & $\mathrm{CH}_{3} \mathrm{OH}$ & $43 \%$ \\
\hline $30^{d}$ & $\mathrm{PdCl}_{2}$ & $\mathbf{L}_{3}$ & $\mathrm{~T}^{+} \mathrm{BF}_{4}^{-}$ & $\mathrm{CH}_{3} \mathrm{OH}$ & $67 \%$ \\
\hline $31^{d}$ & $\mathrm{Pd}\left(\mathrm{PPh}_{3}\right)_{2} \mathrm{Cl}_{2}$ & & $\mathrm{~T}^{+} \mathrm{BF}_{4}^{-}$ & $\mathrm{CH}_{3} \mathrm{OH}$ & $60 \%$ \\
\hline $32^{d}$ & $\mathrm{Pd}\left(\mathrm{PPh}_{3}\right)_{4}$ & & $\mathrm{~T}^{+} \mathrm{BF}_{4}^{-}$ & $\mathrm{CH}_{3} \mathrm{OH}$ & $38 \%$ \\
\hline $33^{d}$ & $\mathrm{Pd}\left(\mathrm{CH}_{3} \mathrm{CN}\right)_{2} \mathrm{Cl}_{2}$ & & $\mathrm{~T}^{+} \mathrm{BF}_{4}^{-}$ & $\mathrm{CH}_{3} \mathrm{OH}$ & $74 \%$ \\
\hline $34^{d}$ & $\mathrm{Pd}(\mathrm{acac})_{2}$ & & $\mathrm{~T}^{+} \mathrm{BF}_{4}^{-}$ & $\mathrm{CH}_{3} \mathrm{OH}$ & $58 \%$ \\
\hline $35^{d}$ & $\mathrm{Pd}(\mathrm{PhCN})_{2} \mathrm{Cl}_{2}$ & & $\mathrm{~T}^{+} \mathrm{BF}_{4}^{-}$ & $\mathrm{CH}_{3} \mathrm{OH}$ & $63 \%$ \\
\hline $36^{d}$ & $\mathrm{Pd}(\operatorname{cod}) \mathrm{Cl}_{2}$ & & $\mathrm{~T}^{+} \mathrm{BF}_{4}^{-}$ & $\mathrm{CH}_{3} \mathrm{OH}$ & $66 \%$ \\
\hline $37^{d}$ & $\operatorname{Pd}\left(\mathrm{PCy}_{3}\right)_{2} \mathrm{Cl}_{2}$ & & $\mathrm{~T}^{+} \mathrm{BF}_{4}^{-}$ & $\mathrm{CH}_{3} \mathrm{OH}$ & $86 \%$ \\
\hline $38^{d}$ & $\mathrm{Pd}\left(\mathrm{PCy}_{3}\right)_{2} \mathrm{Cl}_{2}$ & & & $\mathrm{CH}_{3} \mathrm{OH}$ & Trace \\
\hline $39^{d}$ & & & $\mathrm{~T}^{+} \mathrm{BF}_{4}^{-}$ & $\mathrm{CH}_{3} \mathrm{OH}$ & No \\
\hline
\end{tabular}

${ }^{a}$ Reaction conditions: 1a (0.1 mmol), para-methyphenyl boric acid (1.2 equiv.), catalyst (10 mol\%), ligand $(10 \mathrm{~mol} \%)$ and oxidant (1.2 equiv.) was stirred in solvent $(1 \mathrm{~mL})$ at $60{ }^{\circ} \mathrm{C}$ under Ar for $20 \mathrm{~h} .{ }^{b}$ Yield of the isolated product. ${ }^{c} 100{ }^{\circ} \mathrm{C} .{ }^{d} 80^{\circ} \mathrm{C}$.

entries 9-15). Then, different solvents were screened; using $\mathrm{CH}_{3} \mathrm{OH}$ as the solvent with the set reaction conditions gave comparable results (entry 25), but others gave lower yields (Table 1, entries 16-25). When the temperature was increased to $80{ }^{\circ} \mathrm{C}$, the yield of $2 \mathrm{a}$ reached $71 \%$ (Table 1, entries 26 and 27 ).
To our delight, the reaction could occur in the presence of $10 \mathrm{~mol} \%$ of catalysts such as $\mathrm{Pd}\left(\mathrm{NO}_{3}\right)_{2}, \mathrm{Pd}(\mathrm{TFA})_{2}, \mathrm{PdCl}_{2}$, $\mathrm{Pd}\left(\mathrm{PPh}_{3}\right)_{2} \mathrm{Cl}_{2}, \mathrm{Pd}\left(\mathrm{PPh}_{3}\right)_{4}, \operatorname{Pd}\left(\mathrm{CH}_{3} \mathrm{CN}\right)_{2} \mathrm{Cl}_{2}$, and $\mathrm{Pd}(\text { acac })_{2}$, while the reactivity of $\mathrm{Pd}\left(\mathrm{PCy}_{3}\right)_{2} \mathrm{Cl}_{2}$ was better than others, affording the desired product $2 \mathrm{a}$ in $86 \%$ yield (Table 1, entries 28-37). Furthermore, control experiments showed that no or trace amounts of the desired product was obtained in the absence of $\mathrm{Pd}\left(\mathrm{PCy}_{3}\right)_{2} \mathrm{Cl}_{2}$ or $\mathrm{T}^{+} \mathrm{BF}_{4}{ }^{-}$(Table 1, entries 38 and 39).

With the optimal reaction conditions in hand (Table 1 , entry $37)$, we explored the $\mathrm{C}-\mathrm{H}$ oxidative cross-coupling reaction of 2((4-chlorophenyl)amino)-1-phenylethanone 1a with arylboric acids, as shown in Table 2. We first surveyed different substituents of arylboric acids with electron-donating groups, such as methyl, ethyl, isopropyl and methoxy, and found that they gave the desired product in $80-86 \%$ yields (Table 2, entries 2a-2d). Meanwhile, the steric effect was examined using the meta- and ortho-methyl phenylboric acids under identical conditions (Table 2, entries 2e and 2f). However, the steric effect in this transformation was very significant; only trace amounts of the product was obtained when ortho-methyl phenylboric acids were introduced for the optimization of reaction conditions (Table 2, entry $\mathbf{2 f}$ ). When arylboric acids with different electrondonating or electron-withdrawing groups afforded the desired products in excellent to moderate yields (Table 2, entries $\mathbf{2 g}$ -

\section{Table 2 Reaction conditions screening ${ }^{a, b}$}

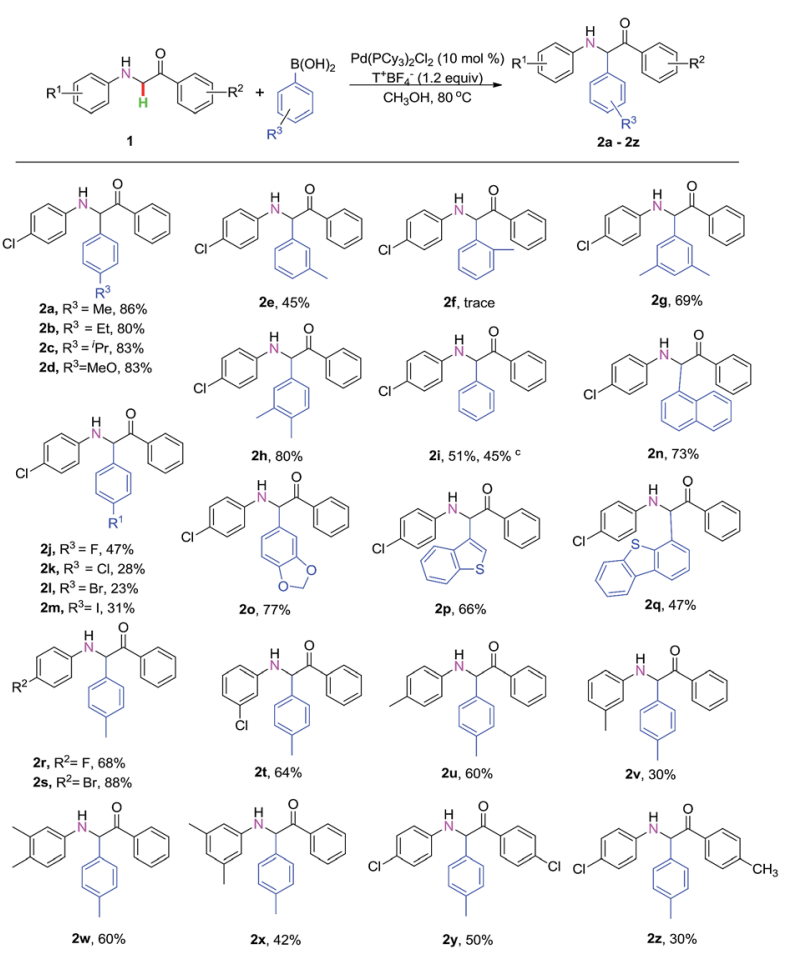

${ }^{a}$ Reaction conditions: 1a $(0.1 \mathrm{mmol})$, para-methyphenyl boric acid (1.2 equiv.), $\mathrm{Pd}\left(\mathrm{PCy}_{3}\right)_{2} \mathrm{Cl}_{2}$ (10 mol\%), and 2,2,6,6-tetramethylpiperidine-1oxoammonium tetra-fluoroborate $\left(\mathrm{T}^{+} \mathrm{BF}_{4}{ }^{-}\right)(1.2$ equiv.) was stirred in $\mathrm{CH}_{3} \mathrm{OH}(1 \mathrm{~mL})$ at $80{ }^{\circ} \mathrm{C}$ under $\mathrm{Ar}$ for $20 \mathrm{~h} .{ }^{b}$ Yield of the isolated product. ${ }^{c}$ Potassium phenyltrifluoroborate as arylated reagents. 


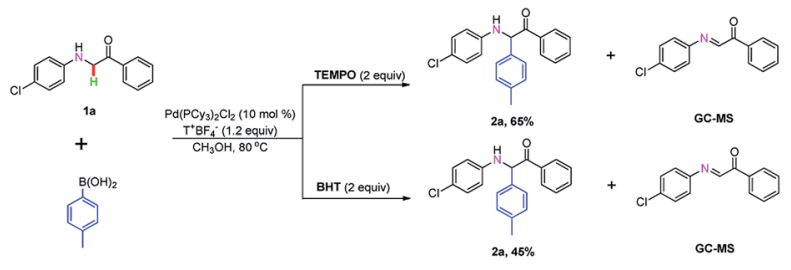

Scheme 2 Radical-trapping experiment.

2m). Moreover, in order to further expand the substrate scope, we selected potassium phenyltrifluoroborate as the arylated reagent under the optimized reaction conditions; the corresponding $\alpha$-alkylation product $2 \mathbf{i}$ was obtained in $45 \%$ yield (Table 2, entry $2 \mathbf{i}$ ).

Furthermore, the naphthalen-1-ylboronic acid and benzo $[1,3]$ dioxol-5-ylboronic acid could also afford $\alpha$-aminocarbonyl compounds $2 \mathbf{n}$ and $2 \mathbf{o}$ in $73-77 \%$ yields (Table 2, entries $2 \mathbf{n}$ and 2o). Of particular note is the heterocyclic boronic acid, which was also compatible for the reaction (Table 2, entries 2p and 2q). Moreover, the introduction of various electron-withdrawing or electron-donating substituents on the aniline moeity gave the corresponding $\alpha$-aminocarbonyl compounds in $30-88 \%$ yields (Table 2, entries 2r-2x); the electronic effect and the steric effect in this transformation was very notable (Table 2, entries $\mathbf{2 t} \mathbf{t}-\mathbf{2 v}$ ). Next, different substituent groups of $\alpha$-carbonyl compounds bearing different functional groups were additionally examined and the corresponding products were generated in moderate yields (Table 2, entries $2 \mathbf{y}$ and $\mathbf{2 z}$ ).

To investigate the mechanism of this transformation, experiments were carried out. The desired product was obtained in the range of $86 \%$ to $65 \%$ and $86 \%$ to $45 \%$ yield when 2.0 equivalents of radical-trapping reagents 2,2,6,6-tetramethyl-1piperidinyloxy (TEMPO) and 2,6-di-tert-butyl-4-methylphenol (BHT) were used, respectively, under standardized reaction conditions (Scheme 2). To our delight, the key $\alpha$-imino intermediate A was detected by GC-MS (see ESI $\dagger$ ). Based on the observed experimental results and pioneering reports, ${ }^{4 p, 9}$ we have described a plausible mechanistic pathway in Scheme 3 . Initially, the arylpalladium intermediate $\mathbf{B}$ was produced via a transmetallation reaction of $\mathrm{Pd}\left(\mathrm{PCy}_{3}\right)_{2} \mathrm{Cl}_{2}$ with aryl boric acid, which attacks the $\alpha$-imino intermediate $\mathbf{A}$ obtained by the in situ oxidation of $\mathbf{1 a}$ by $\mathrm{T}^{+} \mathrm{BF}_{4}{ }^{-}$to form the complex $\mathbf{C}$. Then, an aryl group was added to the imine to generate intermediate $\mathbf{D}$.

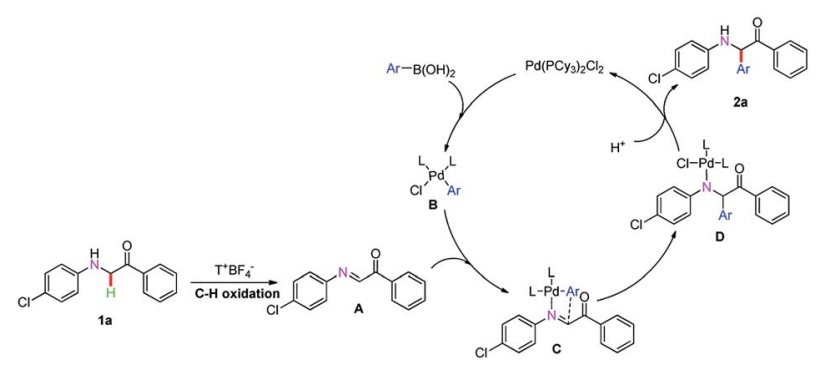

Scheme 3 Proposed mechanism.
Finally, the product 2a was obtained upon dissociation in the presence of $\mathrm{H}^{+}$. At the same time, the palladium catalyst was regenerated and synchronized into the next catalytic cycle (Scheme 3).

In summary, we have achieved a novel pattern for the synthesis of $\alpha$-aryl $\alpha$-amino ketone compounds via $\operatorname{Pd(II)-cata-~}$ lyzed oxidative coupling of $\alpha$-aminocarbonyl compounds with arylboric acids. This reaction occurs via direct $\mathrm{C}-\mathrm{H}$ oxidation and arylation reactions. The coupling of $\alpha$-aminocarbonyl compounds gave functionalized $\alpha$-aryl $\alpha$-amino ketone compounds in moderate to excellent yields.

\section{Conflicts of interest}

There are no conflicts to declare.

\section{Acknowledgements}

This work was financially supported by the National Natural Science Foundation of China (No. 21762038 and 21962016), the Fundamental Research Funds for the Central Universities (31920190077, 31920180040 and 31920190015), the Scientific Research Foundation of Northwest University for Nationalities (xbmuyjrc201603).

\section{Notes and references}

1 (a) S. H. Cho, J. Y. Kim, J. Kwak and S. Chang, Chem. Soc. Rev., 2011, 40, 5068-5083; (b) S. A. Girard, T. Knauber and C.-J. Li, Angew. Chem., Int. Ed., 2014, 53, 74-100; (c) C.-J. Li, Acc. Chem. Res., 2009, 42, 335-344; (d) C.-J. Li and Z. Li, Pure Appl. Chem., 2006, 78, 935; (e) C. J. Scheuermann, Chem.-Asian J., 2010, 5, 436-451; (f) C. S. Yeung and V. M. Dong, Chem. Rev., 2011, 111, 1215-1292; $(g)$ A. H. Cherney, N. T. Kadunce and S. E. Reisman, Chem. Rev., 2015, 115, 9587-9652; (h) C. G. Newton, S.-G. Wang, C. C. Oliveira and N. Cramer, Chem. Rev., 2017, 117, 8908-8976.

2 (a) G. Choudhary and R. K. Peddinti, Green Chem., 2011, 13, 276; (b) M. B. Gawande, V. D. Bonifácio, R. Luque, P. S. Branco and R. S. Varma, Chem. Soc. Rev., 2013, 42, 5522; (c) S. L. Jain, S. Singhal and B. Sain, Green Chem., 2007, 9, 740; (d) G. L. Khatik, R. Kumar and A. K. Chakraborti, Org. Lett., 2006, 8, 2433; (e) M. V. Reddy, B. S. Kumar, K. T. Lim, B. G. Cho and Y. T. Jeong, Tetrahedron Lett., 2016, 57, 476; (f) R. S. Varma, Green Chem., 1999, 1, 43; $(g)$ G. Zhang, Y. Zhang and R. Wang, Angew. Chem., Int. Ed., 2011, 50, 10429-10432; (h) J. Zhang, Z. Cui, F. Wang, Y. Wang, Z. Miao and R. Chen, Green Chem., 2007, 9, 1341; (i) L. Zhao and C.-J. Li, Angew. Chem., Int. Ed., 2008, 47, 7075-7078; (j) Z.-Q. Zhu, P. Bai and Z.-Z. Huang, Org. Lett., 2014, 16, 4881-4883.

3 (a) A. Bodtke and P. Langer, Tetrahedron Lett., 2004, 45, 8741; (b) L. Bryan, A. Richard, K. F. Buzon, T. Chiu, M. L. Colgan and N. Kasthurikrishnan, Tetrahedron Lett., 2004, 45, 6887; (c) V. Chandrashaker, M. Taniguchi, M. Ptaszek and J. S. Lindsey, Tetrahedron, 2012, 68, 6957; (d) B. P. Medaer and G. J. Hoornaert, Tetrahedron, 1999, 55, 3987; (e) 
A. D. Murkute, J. E. Jackson and D. J. Miller, J. Catal., 2011, 278, 189-199; (f) S. H. Gellman, Acc. Chem. Res., 1998, 31, 173-180; (g) M. C. Jose and R.-S. Humberto, Curr. Org. Chem., 2008, 12, 524-543; (h) F. D. Klingler, Acc. Chem. Res., 2007, 40, 1367-1376; (i) Y. Ohfune, Acc. Chem. Res., 1992, 25, 360-366; (j) M. Farahi, F. Tamaddon, B. Karami and S. Pasdar, Tetrahedron Lett., 2015, 56, 1887-1890; $(k)$ F. Tamaddon and A. Dehghani Tafti, Synlett, 2016, 27, 2217-2220.

4 (a) J. Xie and Z.-Z. Huang, Angew. Chem., Int. Ed., 2010, 49, 10181-10185; (b) J. S. Bandar and T. H. Lambert, J. Am. Chem. Soc., 2013, 135, 11799-11802; (c) J. T. Binder, C. J. Cordier and G. C. Fu, J. Am. Chem. Soc., 2012, 134, 17003-17006; (d) C. Huo, C. Wang, M. Wu, X. Jia, H. Xie and Y. Yuan, Adv. Synth. Catal., 2014, 356, 411-415; (e) C. Huo, M. Wu, F. Chen, X. Jia, Y. Yuan and H. Xie, Chem. Commun., 2015, 51, 4708-4711; ( $f$ ) C. Huo, H. Xie, F. Chen, J. Tang and Y. Wang, Adv. Synth. Catal., 2016, 358, 724-730; (g) S. Kotha, Acc. Chem. Res., 2003, 36, 342-351; (h) C. Nájera and J. M. Sansano, Chem. Rev., 2007, 107, 45844671; ( $i$ ) S. Saito, T. Tsubogo and S. Kobayashi, J. Am. Chem. Soc., 2007, 129, 5364-5365; (j) M. Salman, Z.-Q. Zhu and Z.-Z. Huang, Org. Lett., 2016, 18, 1526-1529; (k) B. M. Trost and F. Miege, J. Am. Chem. Soc., 2014, 136, 3016-3019; (l) M. Wan, H. Lou and L. Liu, Chem. Commun., 2015, 51, 13953-13956; $(m)$ E. W. Werner, T.-S. Mei, A. J. Burckle and M. S. Sigman, Science, 2012, 338, 1455-1458; (n) Z.-Y. Xue, Q.-H. Li, H.-Y. Tao and C.-J. Wang, J. Am. Chem. Soc., 2011, 133, 11757-11765; (o) Y. Hui, X. Yilan, D. Rui and F. Yan, Adv. Synth. Catal., 2017, 359, 39-43; (p) X.-H. Wei, G.-W. Wang and S.-D. Yang, Chem. Commun., 2015, 51, 832835; (q) X.-H. Wei, L.-B. Zhao and H.-C. Zhou, RSC Adv., 2017, 7, 16561-16564; (r) Y. Wei, J. Wang, Y. Wang, X. Yao, C. Yang and C. Huo, Org. Biomol. Chem., 2018, 16, 49854989; (s) Y. Zhang, X. Yang, H. Zhou, S. Li, Y. Zhu and Y. Li, Org. Chem. Front., 2018, 5, 2120-2125; $(t)$ R. V. Daggupati and C. Malapaka, Org. Chem. Front., 2018, 5, 788-792; (u) L. Revathi, L. Ravindar, W.-Y. Fang, K. P. Rakesh and H.-L. Qin, Adv. Synth. Catal., 2018, 360, 4652-4698; (v) X.-H. Wei, L.-B. Zhao and H.-C. Zhou, RSC Adv., 2017, 7, 16561-16564; $(w)$ G.-F. Zha, G. A. L. Bare, J. Leng, Z.-P. Shang, Z. Luo and H.-L. Qin, Adv. Synth. Catal., 2017, 359, 3237-3242; (x) X. Zhang, K. P. Rakesh, L. Ravindar and H.-L. Qin, Green Chem., 2018, 20, 4790-4833; (y) C. Zhao, G.-F. Zha, W.-Y. Fang, K. P. Rakesh and H.-L. Qin, Eur. J. Org. Chem., 2019, 2019, 1801-1807.

5 (a) J.-C. Wu, R.-J. Song, Z.-Q. Wang, X.-C. Huang, Y.-X. Xie and J.-H. Li, Angew. Chem., Int. Ed., 2012, 51, 3453-3457; (b) W.-T. Wei, R.-J. Song and J.-H. Li, Adv. Synth. Catal., 2014, 356, 1703-1707.
6 (a) P. Liu, Y. Li, H. Wang, Z. Wang and X. Hu, Tetrahedron Lett., 2012, 53, 6654-6656; (b) P. Liu, Z. Wang, J. Lin and X. Hu, Eur. J. Org. Chem., 2012, 2012, 1583-1589; (c) H. Richter and O. García Mancheño, Org. Lett., 2011, 13, 6066-6069; (d) R. Rohlmann, T. Stopka, H. Richter and O. García Mancheño, J. Org. Chem., 2013, 78, 6050-6064; (e) Z.-Q. Wang, M. Hu, X.-C. Huang, L.-B. Gong, Y.-X. Xie and J.-H. Li, J. Org. Chem., 2012, 77, 8705-8711; (f) W.-T. Wei, R.-J. Song and J.-H. Li, Adv. Synth. Catal., 2014, 356, 17031707; $(g)$ L. Zhao, O. Baslé and C.-J. Li, Proc. Natl. Acad. Sci. U. S. A., 2009, 106, 4106-4111; (h) X.-X. Liu, Z.-Y. Wu, Y.-Q. He, X.-Q. Zhou, T. Hu, C.-W. Ma and G.-S. Huang, Adv. Synth. Catal., 2016, 358, 2385-2391; (i) Z. Xie, J. Jia, X. Liu and L. Liu, Adv. Synth. Catal., 2016, 358, 919-925.

7 B. Yang, T.-T. Yang, X.-A. Li, J.-J. Wang and S.-D. Yang, Org. Lett., 2013, 15, 5024-5027.

8 (a) M.-X. Cheng, R.-S. Ma, Q. Yang and S.-D. Yang, Org. Lett., 2016, 18, 3262-3265; (b) Y.-Y. Huang, C. Cai, X. Yang, Z.-C. Lv and U. Schneider, ACS Catal., 2016, 6, 5747-5763; (c) Z. Meng, S. Sun, H. Yuan, H. Lou and L. Liu, Angew. Chem., Int. Ed., 2014, 53, 543-547; (d) S. Stockerl and O. G. Mancheno, Org. Chem. Front., 2016, 3, 277-280; (e) S. Sun, C. Li, P. E. Floreancig, H. Lou and L. Liu, Org. Lett., 2015, 17, 1684-1687; $(f)$ S. Sun, Y. Mao, H. Lou and L. Liu, Chem. Commun., 2015, 51, 10691-10694; $(g)$ Z. Xie, X. Zan, S. Sun, X. Pan and L. Liu, Org. Lett., 2016, 18, 3944-3947; (h) J. Chen, X. Lu, W. Lou, Y. Ye, H. Jiang and W. Zeng, J. Org. Chem., 2012, 77, 8541-8548; (i) A. Córdova, Acc. Chem. Res., 2004, 37, 102-112; (j) N. Gommermann, C. Koradin, K. Polborn and P. Knochel, Angew. Chem., Int. Ed., 2003, 42, 5763-5766; ( $k$ ) M. Hatano, T. Horibe and K. Ishihara, J. Am. Chem. Soc., 2009, 132, 56-57; (l) K. R. Knudsen, T. Risgaard, N. Nishiwaki, K. V. Gothelf and K. A. Jørgensen, J. Am. Chem. Soc., 2001, 123, 5843-5844; ( $m$ ) S. Kobayashi, T. Hamada and K. Manabe, J. Am. Chem. Soc., 2002, 124, 5640-5641; (n) S. Kobayashi, Y. Mori, J. S. Fossey and M. M. Salter, Chem. Rev., 2011, 111, 2626-2704; (o) C. Koradin, K. Polborn and P. Knochel, Angew. Chem., Int. Ed., 2002, 41, 2535-2538; ( $p$ ) C. Qian, J. Chen, M. Fu, S. Zhu, W.-H. Chen, H. Jiang and W. Zeng, Org. Biomol. Chem., 2013, 11, 6013-6022; (q) A. E. Taggi, A. M. Hafez and T. Lectka, Acc. Chem. Res., 2002, 36, 10-19; (r) B. M. Trost and L. R. Terrell, J. Am. Chem. Soc., 2002, 125, 338-339; (s) C. Wei and C.-J. Li, J. Am. Chem. Soc., 2002, 124, 5638-5639; (t) C. Wei, J. T. Mague and C.-J. Li, Proc. Natl. Acad. Sci. U. S. A., 2004, 101, 5749-5754; (u) C.-Y. Zhou, S.-F. Zhu, L.-X. Wang and Q.-L. Zhou, J. Am. Chem. Soc., 2010, 132, 10955-10957.

9 (a) R. Bloch, Chem. Rev., 1998, 98, 1407-1438; (b) H. Dai and X. Lu, Org. Lett., 2007, 9, 3077-3080; (c) S. Kobayashi and H. Ishitani, Chem. Rev., 1999, 99, 1069-1094. 